SECTION 1

Caribbean Encounters 
Wim Klooster - 9789004271319

Downloaded from Brill.comఠ4/26/2023 03:29: 03PM via free access 


\title{
Curaçao as a Transit Center to the Spanish Main and the French West Indies
}

\author{
Wim Klooster
}

An official Dutch government report described Curaçao in the late eighteenth century as "the only safe port that the state has in the West Indies, one in which more than 300 ships of the largest size can be sheltered and where they are shielded against the force of wind and sea, where all the ships can be keelhauled and recover from sustained damage, where a defeated fleet or merchantmen coming from our colonies can always flee because of its leeward location..."1 Ideal for shipping traffic, the island had long since been an important regional market, described by a contemporary author as a "small paradise of earthly abundance." ${ }^{2}$ The aim of this chapter is to review the island's commercial heyday, its connections with the Republic, its place in Caribbean trade networks, and the concomitant mobility of its populations.

Captured from Habsburg Spain during the last stages of the Dutch Revolt, Curaçao did not immediately become a center of commercial activity. It began its life under Dutch rule as a naval base. Although some military raids were launched from the island to inflict damage on settlements on the Venezuelan coast, Curaçao did not play a key role in the Atlantic theater of the war with Spain. The West India Company even considered abandoning the former Spanish cattle ranch in the startup years. It was not until the late 1650 , a decade after the Dutch Republic and Spain had signed the Treaty of Münster (1648), that trade - especially with nearby Spanish colonies - became the island's lifeblood. In the eighteenth century, Curaçao also forged close ties with the French Caribbean, a connection that historians have virtually ignored.

The transformation of Curaçao from a sleepy, sparsely inhabited island to a bustling commercial hub was a rapid one. Even before the Dutch West India Company (WIC) declared Willemstad a free port in 1675, Curaçao had earned a reputation for the wide array of European manufactures and African slaves available for sale. Often in defiance of foreign mercantilist laws, the island's

1 National Archives of the Netherlands, The Hague (hereafter NL-HaNA), Verspreide Westindische Stukken, 1.05.06, inv. no. 972, report of W.A.I. van Grovestein and W.C. Boeij, The Hague, 11 February 1791.

2 J.H. Hering, Beschryving van het eiland Curaçao en de daar onder hoorende eilanden, Bonaire, Oroba en Klein Curaçao. Benevens een kort bericht, wegens het gesprongen schip Alphen (Amsterdam: J.V. Selm, 1779), 59 .

(C) WIM KLOOSTER, 2014 | DOI 10.1163/9789004271319_003

This is an open access chapter distributed under the terms of the Creative Commons

Attribution-Noncommercial 3.0 Unported (CC-BY-NC 3.0) License. 
pioneer merchants established commercial contacts with English settlers in North America and populations across the Greater Caribbean. The buttress of Curaçao's trade was the business conducted in Spanish America, in particular the nearby Spanish Main. Venezuela was a rich provider of tobacco and hides and, especially, cacao, of which it was the world's leading producer. The regions to its West between Panama and Río Hacha offered copious amounts of silver, which the Dutch usually received in exchange for their supplies at Portobelo. In the first half of the eighteenth century, this was the source of virtually all cash on Curaçao. ${ }^{3}$ Many sloops and schooners also left Willemstad for Cuba, Puerto Rico, and Santo Domingo. So intensive and valuable was the traffic with these areas that authorities in metropolitan Spain came to view Curaçao along with Colônia do Sacramonte in the Southern Cone of South America as the two main gates through which smuggled goods entered the Spanish colonies. ${ }^{4}$ In view of the scope of the illegal trade, the administrator of the coast guard of Florida and Cuba therefore once suggested that the Spanish invade Curaçao. He called the island one of the worst "hangnails" in America. ${ }^{5}$

British and Dutch vessels also established trade links between the Thirteen Colonies and the Dutch island. Due to its poor soil and lack of rainfall, Curaçao was unable to produce its own food. Provisions had to be imported, first from the Dutch Republic, but soon most foodstuffs were supplied by North American merchants and imported by English subjects residing on the island. ${ }^{6}$ A voyage from New York took only three weeks, while ocean-going

3 NL-HaNA, Tweede West-Indische Compagnie (NWIC), 1.05.01.02, inv. no. 1155, Governor Jan Noach du Faij to the wIC, Chamber of Zeeland, Curaçao, 20 December 1730. This wealth of silver explains why returns to the Dutch Republic involved the remittance of sealed bags of silver as frequently as bills of exchange. Cf. John J. McCusker, Money and Exchange in Europe and America, 1600-1775: A Handbook (Chapel Hill: The University of North Carolina Press, 1978), 293. Conversely, in times of slack trade the island virtually lacked cash. In 1753, local merchants eager to keep their creditors satisfied went to the extreme of sending silver kitchen utensils to the Dutch Republic: NL-HaNA, WIC, 1.05.01.02, inv. no. 1161, fol. 13, J.G. Pax and Nathaniel Ellis to governor Isaac Faesch, 24 September 1753 .

4 NL-HaNA, Fagel, 1.10.29, inv. no. 1784, unsigned letter to Grand Pensionary Stein, Antigola, 21 June 1731 .

5 Lance Grahn, The Political Economy of Smuggling: Regional Informal Economies in Early Bourbon New Granada (Boulder, Colorado: Westview Press, 1997), 50-51.

6 NL-HaNA, WIC, 1.05.01.02, inv. no. 1160, fol. 91, Governor Isaac Faesch to the wIC, Chamber of Amsterdam, Curaçao, 16 February 1751. The New York company of John and Henry Cruger sent 56 vessels with flour, bread, and other foodstuffs to Curaçao in the years 1762-1768, using their relative Teleman Cruger as their local agent: New York Historical Society, 442.1, John \& Henry Cruger, Wastebook 1762-1768. 
Dutch ships often needed several months to complete the trip to Curaçao, frequently causing the provisions to decay. Besides, the New Yorkers and New Englanders offered their provisions at a lower price. In 1724, for example, flour from New York cost 14 cents, that from the Netherlands at least 18 cents per pound. ${ }^{7}$ Dependence on these supplies could become a liability in wartime. During the War of Jenkins' Ear (1739-1748), fought in the Caribbean between Britain and Spain, the governor of New York refused to sell even one barrel of flour or meat to the Curaçaoans, causing serious embarrassment on the Dutch island. ${ }^{8}$

From an early date, the commercial fortunes of Curaçao were linked to the interimperial slave trade. In 1642, a West India Company official first suggested to make the island a transit center in the slave trade from Luanda to the Spanish Caribbean. Portuguese merchants had traditionally provided ports such as Veracruz and Cartagena with bonded Central Africans whom they had embarked in Luanda, but that town had fallen into Dutch hands the year before. ${ }^{9}$ While this plan failed to materialize, some 15 years later Dutch slave ships began to call at Curaçao and sell their human cargoes. The creation of a slave market on the island fulfilled economic needs for both sides involved. Dutch slave traders had survived the collapse of Brazil by selling slaves to foreign colonies, but the notion of a reliable single market must have been attractive to them. At the same time, a Spanish colonist took the initiative to approach Curaçao's Director Mathias Beck and suggest he sell slaves in Portobelo in order to blaze a trail by which settlers on the Spanish Main would come and trade for slaves in the future. ${ }^{10}$ The trade in humans was so successful that the Genoese holders of the asiento, the monopoly of slave shipments to Spanish America, signed a contract with the Dutch West India Company in 1662 that allowed them to buy slaves in Curaçao. The trend was thus set for the decades to come, during which the island became the largest transit port in the inter-American slave trade. The slave trade to Venezuela and New Granada was not even interrupted by the War of the Spanish Succession (1702-1713), which found the Dutch suppliers and their Spanish American

7 NL-HaNA, wic, 1.05.01.02, inv. no. 1154, Governor Jan Noach du Faij to the wic, Chamber of Zeeland, Curaçao, 20 October 1724.

8 NL-HaNA, wIC, 1.05.01.02, inv. no. 1157, fol. 144, governor Isaac Faesch to the wIC, Chamber of Amsterdam, Curaçao, 12 September 1741.

9 W.R. Menkman, "Nederlandsche en vreemde slavenvaart," De West-Indische Gids 26 (1944): 97-111.

10 Mathias Beck to the wic, Curaçao, 28 July 1657, in Curacao Papers 1640-1665, New Netherland Documents, vol.17, ed. Charles T. Gehring and J.A. Schiltkamp (Interlaken, NY: Heart of the Lakes Publishing, 1987), 104-105. 
customers in opposite camps. ${ }^{11}$ In all, some 70,00o slaves found their way from

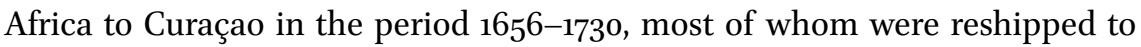
Spanish colonies. ${ }^{12}$ For those deemed unfit for Spanish bondage, Curaçao was their final destination. In these years, Han Jordaan has argued, "nearly every free person seems to have been involved in the slave trade to some degree."13

Once the regular availability of enslaved Africans attracted customers from the Spanish colonies, Dutch merchants began to offer a wide variety of dry goods for sale. As a consequence, their purchases of products grown in foreign parts of the Americas increased rapidly. By 1663, large amounts of Venezuelan cacao were already being exported from Curaçao to the Dutch Republic. The proximity to Venezuela, the world's largest cacao producer, allowed the Dutch to play a large role in the transatlantic cacao trade and Amsterdam to become one of the foremost global cacao markets. The holds of ships leaving Curaçao for Dutch metropolitan ports also included tobacco from Cuba, Puerto Rico, Venezuela, and Santo Domingo, sugar and coffee from the French West Indies, as well as indigo, logwood, and hides. Besides, bullion and specie from the Spanish Main accounted for more than a quarter of the value of the homebound cargoes.

International warfare greatly enhanced the fortunes of the Dutch entrepôt. Trade was especially brisk during the War of Jenkins' Ear, the Seven Years' War (1756-1763), and the War of American Independence (1775-1783), but declined once peaceful relations returned and foreign authorities could focus on the fight against smugglers. The 1730 s and the early 1750 stand out as periods in which officials in Venezuela successfully blocked the Curaçaoans' access to local products, creating hardship on the Dutch island. ${ }^{14}$ During the Seven Years' War, merchants from Curaçao and St. Eustatius were so active in their trade with Saint-Domingue that they helped maintain commercial communication between France and the Antilles. ${ }^{15}$ Due to Dutch

11 Cornelis Ch. Goslinga, "Curaçao as a slave-trading center during the War of the Spanish Succession (1702-1714)," Nieuwe West-Indische Gids 52 (1977): 1-50.

12 Johannes Menne Postma, The Dutch in the Atlantic Slave Trade, 1600-1815 (New York: Cambridge University Press, 1990), 54.

13 Han Jordaan, "The Curaçao Slave Market: From Asiento Trade to Free Trade, 1700-1730," in Riches from Atlantic Commerce: Dutch Trans-Atlantic Trade and Shipping, 1585-1817, ed. Johannes Postma and Victor Enthoven (Leiden and Boston: Brill, 2003), 219-57, 256.

14 Wim Klooster, Illicit Riches: Dutch Trade in the Caribbean, 1648-1795 (Leiden: KITLV Press, 1998), 149, 168, 175 .

15 Philippe Chassaigne, "L'économie des îles sucrières dans les conflits maritimes de la seconde moitié du XVIIIème siècle," Histoire, économie et société 7, no. 1 (1988): 93-105, 101. 
neutrality, Curaçao's trade with the belligerents also thrived in the season of war. When, in 1779, France's participation in the American War of Independence $\left(1775^{-1783}\right)$ induced French authorities to invite all nations, except the British, to come and trade freely, many Curaçaoan shipowners heeded the call. ${ }^{16}$

\section{Connections with the French Antilles}

All of this has been documented and distilled in monographs. ${ }^{17}$ What has been understudied are the commercial ties with the French Caribbean and the eighteenth-century slave trade. Curaçao's French connections assumed a growing significance in the course of the eighteenth century due to the economic development of Martinique, Guadeloupe, and especially the Southern parts of Saint-Domingue. Historians have overlooked the vital link Curaçao provided between the French colonies and the Spanish American markets. ${ }^{18}$ Thus, in the 1740s, French merchants based in the French colonies sold silk products to shipowners on Curaçao, making a handsome profit, since their merchandise was cheaper than the same French silk arriving on Dutch ships

16 NL-HaNA, wIC, 1.05.01.02, inv. no. 1168, fols. 641-642, Governor Jean Rodier to the wIC, Chamber of Amsterdam, Curaçao, 28 January 1779. See also Isaac S. Emmanuel and Suzanne A. Emmanuel, History of the Jews of the Netherlands Antilles (Cincinnati: American Jewish Archives, 1970), 829.

17 Curaçao: Celestino Andrés Arauz Monfante, El contrabando holandés en el Caribe durante la primera mitad del siglo XVIII, 2 vols. (Caracas: Academia Nacional de la Historia, 1984); Ramón Aizpurua, Curazao y la costa de Caracas: Introducción al estudio del contrabando de la Provincia de Venezuela en tiempos de la Compañía Guipuzcoana (Caracas: Academia Nacional de la Historia, 1993); Grahn, Political Economy of Smuggling; Klooster, Illicit Riches; Jeremy David Cohen, "Cultural and Commercial Intermediaries in an Extra-Legal System of Exchange: The Prácticos of the Venezuelan Littoral in the Eighteenth Century," Itinerario 27, no. 2 (2003), 105-124. St. Eustatius: Richard Pares, War and Trade in the West Indies, 1739-1763 (New York: Oxford University Press, 1936); Cornelis Ch. Goslinga, The Dutch in the Caribbean and in the Guianas 1680-1791 (Assen, Maastricht and Dover, N.H.: Van Gorcum, 1985); Michael J. Jarvis, In the Eye of All Trade: Bermuda, Bermudians, and the Maritime Atlantic World, 1680-1783 (Chapel Hill: University of North Carolina Press, 2010); Victor Enthoven, "That Abominable Nest of Pirates': St. Eustatius and the North Americans, 1680-1780," Early American Studies 10, no. 2 (2012): 239-301.

18 See also NL-HaNA, WIC, 1.05.01.02, inv. no. 474, fol. 176, W. Backer and W. Roëll to Governor Isaac Faesch, Amsterdam, 11 June 1743. 
from Amsterdam. ${ }^{19}$ In the second half of the century, the French islands sent large amounts of syrup, rum, and brandy to Curaçao.

In the first quarter of the eighteenth century, Curaçao became a transit point in the mule trade from Tierra Firme to the French colonies, a business that eventually developed into the main branch of Curaçao's commerce. ${ }^{20}$ Mules were used as a mode of transport and as pack animals, but predominantly as draft animals on Caribbean sugar plantations. Because of their strength, their short lifespan, and their inability to reproduce, they were in perennial demand. As early as 1723 , the governor of Coro (Venezuela) complained about the annual export of 1500 mules to Caribbean islands by way of Curaçao. ${ }^{21}$ Curaçaoan sailors were soon experts in handling and transporting these animals, which they often introduced illegally in Curaçao by steering their vessels to the island's outer bays. ${ }^{22}$ In the early years of the nineteenth century, Alexander von Humboldt witnessed the embarkation of mules in Puerto Cabello (Venezuela): "They are thrown down with ropes, and then hoisted on board the vessels by means of a machine resembling a crane. Ranged in two files, the mules with difficulty keep their footing during the rolling and pitching of the ship; and in order to frighten and render them more docile, a drum is beaten during a great part of the day and night." ${ }^{23}$ The tendency of the mules to kick and bite made it easy to smuggle all kinds of goods on the vessels carrying them, since customs collectors preferred safety over vigilance. ${ }^{24}$

The French Caribbean import of the mules, whose role in the sugar mills was crucial, took off dramatically in the second half of the century. In the year 1786, French planters imported 6487 mules from the Spanish Main and on the eve of the Haitian Revolution, 50,00o mules were counted in Saint-Domingue, where a single plantation could use 80 of these animals. Not all of these ani-

19 Walter Bodmer, "Tropenkaufleute und Plantagenbesitzer in Niederländisch-Westindien im 18. und zu Beginn des 19. Jahrhunderts," Acta Tropica 3 (1946): 289-321, 304.

20 NL-HaNA, WIC, 1.05.01.02, inv. no. 6o9, fol. 556, Governor Jean Rodier and Council to the WIC, 14 March 1774. According to one French author in 1780, Dutch merchants from Curaçao and St. Eustatius almost completely controlled the mule trade to the French colonies: Weuves, le jeune, Réflexions historiques et politiques sur le commerce de France avec ses colonies de l'Amérique (Genève: L. Cellot, 1780), 54.

21 Arauz Monfante, Contrabando holandés, 1: 105.

22 NL-HaNA, WIC, 1.05.01.02, inv. no. 209, fol. 454, placard issued by Governor Jan Gales, 15 January 1739.

23 Alexander von Humboldt, Personal Narrative of Travels to the Equinoctial Regions of America, during the years 1799-1804, 3 vols. (London: George Bell and Sons, 1889), 2: 46.

24 G.B. Bosch, Reizen in West-Indië, 2 vols. (Amsterdam: S. Emmering, 1985), 1: 310-311. 
mals, incidentally, originated on the Spanish Main. They were also imported from Poitou, France, and in small numbers from the Greater Antilles. ${ }^{25}$

Venezuelan traders needed the mule business in order to finance their slave purchases in foreign colonies, as bonded Africans were always in demand and not regularly supplied through the regular channels. The main alternative, cacao, could not be legally shipped out, at least until 1777, when the Spanish authorities in Venezuela legalized trade with the French colonies. Although Curaçao remained off limits to traders from the mainland, Dutch merchants kept a firm hold on the mule trade. ${ }^{26}$ Nor was it in anybody's interest to sideline the Curaçaoans, on whom French merchants continued to call, since they valued the commercial networks they maintained in Venezuela and New Granada. ${ }^{27}$ The Curaçaoans also received support from the island's governor, Jean Rodier, who exempted the sloops active in this trade from paying import duties, as long as they sailed on after taking in water and provisions. ${ }^{28}$ Curaçao did not always serve as a transit port in the mule trade. Not only did some

25 Ramón Aizpurua A guirre., "Las mulas venezolanas y el Caribe Oriental del siglo XVIII: datos para una historia olvidada," Boletín Americanista 30, no. 38 (1998): 5-15: 8, 10. Jacques de Cauna, Au temps des isles à sucre: Histoire d'une plantation de Saint-Domingue au XVIII ${ }^{e}$ siècle (Paris: Karthala, 1987), 13, 44. Philibert Chabert, Pierre Flandrin and Jean-Baptiste Huzard, Instructions et observations sur les maladies des animaux domestiques, 6 vols., 3rd ed. (Paris: De L'Imprimerie et dans le Librairie Vétérinaire de Madame Huzard, 1808), 3: 307

26 Ángel López Cantos, Don Francisco de Saavedra: Segundo intendente de Caracas (Sevilla: Escuela de Estudios Hispano-Americanos de Sevilla, 1973), 102. At times, Aruba was used as a way station in the mule trade between the Coro region and Curaçao: Vicente de Amézaga Aresti, Vicente Antonio de Icuza, comandante de corsarios (Caracas: Comisión Nacional de Cuatricentenario de Caracas, 1966), 50. Chabert, Flandrin and Huzard, Instructions et observations sur les maladies, 3: 292.

27 Jean Tarrade, "Le commerce entre les Antilles françaises et les possessions espagnoles d'Amérique à la fin du XVIIIe siècle," in Commerce et plantation dans la Carä̈be XVIII et XIX siècles: Actes du Colloque de Bordeaux, 15-16 mars 1991, ed. Paul Butel (Bordeaux: Maison des Pays Ibériques, 1992), 27-43: 30, 36. Merchants on the French islands did not exclusively rely on the Curaçaoans. See, for example, the ill-fated voyage in 1763 of a ship from Martinique to Venezuela, where the captain had intended to buy mules: Ramón Aizpurua Aguirre, "El corso de la Compañía Guipuzcoana: los casos de la lancha San Fernando y de la balandra Nuestra Señora de Aranzazu," Itsas Memoria. Revista de Estudios Marítimos del País Vasco, 5 (2006): 379-92, 389.

28 NL-HaNA, WIC, 1.05.01.02, inv. no. 612, fol. 645, C.A. Roelans, customs collector, and Michiel Römer, bookkeeper, to the wIC, Curaçao, 4 April 1783. The WIC ordered the Curaçaoan government to collect the customs, although it is unlikely that this ever happened: NL-HaNA, wIC, 1.05.01.02, inv. no. 612, fol. 1054, C.A. Roelans to the wIC, Curaçao, 26 March 1784 . 
mules originate on the island itself, a number of local traders carried on a direct trade from the Venezuelan coast to the French islands, while others shipped the animals to Jamaica. ${ }^{29}$

The mules' main destination was Saint-Domingue, whose planters paid in cash crops, their sugar shipments accounting for almost 90 percent of Curaçao's French West Indian sugar imports in the period $1736-1755^{30}$ In the decades that followed, this flow of sugar must have increased further, as Saint-Domingue developed into the world's largest producer of the sweet substance, but data are missing to confirm this hypothesis. The re-export of French colonial products from Curaçao and St. Eustatius to the Dutch Republic reached such heights that an interruption in commerce seriously hurt merchants in the Dutch Republic. The interruptions were not always caused by privateers. When the French army invaded Dutch territory in 1747 in the closing stages of the War of the Austrian Succession, the States General responded by banning the export of "French" refined sugar. More than 100 Amsterdam merchants, virtually making up the entire merchant elite, then signed a request to exempt the sugar that entered the Republic by way of the Dutch Caribbean islands. ${ }^{31}$

In view of the economic dependence on Saint-Domingue, which only increased in the second half of the century, the Haitian Revolution was an unmitigated disaster for the Curaçaoan economy, contributing to the island's decline in the late eighteenth century. Curaçao's leading merchant, David Morales, who owned property in the French colony, was hard hit, but many

29 See, for example, NL-HaNA, 1.05.12.01, Curaçao, Bonaire en Aruba tot 1828, 1.05.12.01, inv. no. 881, fol. 42, for Curaçaoan shipments from the Bight of Maracaibo to Saint-Domingue in 1761 . For the transport to Jamaica, see NL-HaNA, 1.05.12.01, inv. no. 1555 , fols. $76-77$. The shipment of mules from Ríohacha, the Guajiro coast, and Venezuela to Jamaica was, however, mostly in the hands of English and Spanish subjects: Héctor R. Feliciano Ramos, El contrabando inglés en el Caribe y el Golfo de México (1748-1778) (Sevilla: Excma. Diputación Provincial de Sevilla, 1990), 213-214; Gerardo Andrade González, "El negro: Factor esencial de la economía colonial en la gobernación de Popayán del Nuevo Reino de Granada," Revista de Historia de América, no. 120 (Jul-Dec 1995): 35-66, 52; Grahn, Political Economy of Smuggling, 45, 63, 95. Curaçao's mule trade did not disappear overnight: Martinus Stuart, Jaarboeken van het koningrijk der Nederlanden Het jaar 1818. Tweede stuk (Amsterdam: E. Maaskamp, 1823), 107; Tomás Pérez Tenreiro, ed., Angel Laborde y Navarro, capitán de navio: Relación documental de los sucesos de Venezuela, 1822-1823 (Caracas: Instituto Panamericano de Geografía e Historia, 1974), 213, 221.

30 Calculated on the basis of Klooster, Illicit Riches, 235.

31 NL-HaNA, Staten-Generaal, 1.01.02, inv. no. 5782, J. van Loon and P. Backer, Directors of the WIC, to the States General, Amsterdam, 9 January 1748. 
others were ruined. ${ }^{32}$ The island's governor-general would later write that ever since the revolt in Saint-Domingue "entire families have been reduced to beggary. Swarms of beggars, white, colored and black, are seen these days in the streets, inconveniencing the passers-by." ${ }^{33}$ The loss of Saint-Domingue as a trading partner, nonetheless, was not the sole reason for Curaçao's economic decline. At an earlier date, commerce with Portobelo, traditionally a major supplier of specie, had begun to fall off by the 1770s, when at most one vessel returned from that port and then with a cargo that was hardly valuable. ${ }^{34}$ Trade with nearby Venezuela continued to thrive, but was increasingly controlled by merchants on the Spanish Main and conducted in their vessels, a stark contrast with the days when Curaçaoan vessels had accounted for the bulk of this trade. ${ }^{35}$ The War of American Independence offered Curaçao's traders a reprieve, but by the late 1780 s a slump set in. The number of vessels arriving in Willemstad declined by more than half in the decade after $1786 .{ }^{36}$ Ships from the United States even began to transport Caribbean produce from Curaçao to the Netherlands. ${ }^{37}$ Curaçao had seen booms and busts before, but no new heyday would follow this steep decline. Having ranked behind Suriname throughout the eighteenth century in terms of the volume and value of products shipped to the Republic, after 1788 Curaçao also fell behind St. Eustatius. ${ }^{38}$

Similar to Curaçao, St. Eustatius or "Statia" was an important Caribbean transit center. Settled in 1636 , the island had gradually forged commercial ties with foreign colonies in its vicinity. By 1688, eight ocean-going ships left from

32 Emmanuel and Emmanuel, Jews of the Netherlands Antilles, 717.

33 J. de Hullu, "Curaçao in 1817," Bijdragen tot de Taal-, Land-en Volkenkundevan NederlandschIndië 67 (1913): 563-6o9, 569 .

34 NL-HaNA, WIC, 1.05.01.02, inv. no. 1166, fol. 63, Governor Jean Rodier to the wIC, Chamber of Amsterdam, Curaçao, 8 May 1775 .

35 Vessels fitted out at the Spanish Main only occasionally called at Willemstad. These visits usually involved ships en route to Veracruz, Santo Domingo or Puerto Rico, carrying more cacao than had been registered. Klooster, Illicit Riches, 128.

36 NL-HaNA, wIC, 1.05.01.02, inv. no. 612, fols. 747-48, Governor Johannes de Veer to the WIC directors, Curaçao, 11 August 1783. Wim Klooster, "Curaçao and the Caribbean Transit Trade," in Riches from Atlantic Commerce: Dutch Trans-Atlantic Trade and Shipping, 15851817, ed. Johannes Postma and Victor Enthoven, 203-18, 206.

37 P.J. van Winter, Het aandeel van den Amsterdamschen handel aan den opbouw van het Amerikaansche Gemeenebest, 2 vols. ('s-Gravenhage: Martinus Nijhoff, 1933), 2: 96-97.

38 In 1790-93, 150 merchantmen arrived in Amsterdam from Suriname, 83 from St. Eustatius and 30 from Curaçao: W.F.H. Oldewelt, "De Scheepvaartsstatistiek van Amsterdam in de $17^{\mathrm{e}}$ en $18^{\mathrm{e}}$ eeuw," Jaarboek Amstelodamum 45 (1953): 114-151, 130-149. 
the island with Amsterdam as their destination, their cargoes filled with sugar from the surrounding French and English islands. ${ }^{39}$ Attracting merchants looking for both provisions and dry goods, St. Eustatius did not depend on commercial expertise from Curaçao. It was perfectly capable of standing on its own two feet. Beef and salted fish from Ireland and North American flour were always available, while Dutch imports included hats, stockings, spices, paper, glassware, axes, pots, printed cotton fabric, and coarse linen from Osnabrück, Germany. ${ }^{40}$ If Curaçao had become a commercial bridge between the Spanish Main and the French West Indies, a major feature of Statia's commerce in the eighteenth century was its role in facilitating trade between French and British merchants. The governor of St. Christopher (St. Kitts) correctly opined: "The pretence of the Dutch buying of the English and then selling to the French is a mere fallacy. The produce of all St. Eustatius is not above 500 or 600 of our hogsheads of sugar a year...The English and French vessels meet there and deal together as principals, or they have their agents, Steward and Sagran, for the purpose. The Dutch have no concern but to receive the company's duties." ${ }^{41}$ From neighboring Guadeloupe alone, 55 vessels arrived at Statia in 1733 carrying sugar, rum, and molasses, for which there were always British American customers. ${ }^{42}$ In exchange, the Guadeloupeans received slaves and provisions. Guadeloupe's dependence on Statian foodstuffs was such that its merchants were given permission at least three times between $1749-175^{1}$ to purchase provisions in the Dutch island. ${ }^{43}$

39 Victor Enthoven, "That Abominable Nest of Pirates," 252.

40 L. Knappert, Geschiedenis van de Nederlandsche Bovenwindsche eilanden in de 18de eeuw ('s-Gravenhage: Martinus Nijhoff, 1932), 221. Lucien René Abenon, La Guadeloupe de 1671 à 1759: Etude politique, économique et sociale, 2 vols. (Paris: Editions L'Harmattan, 1987), 2:12. William Mathew, governor of St. Christopher, to the Council of Trade and Plantations, 26 May 1737, in Calendar of State Papers Colonial, America and West Indies, vol. 43 (London: Her Majesty's Stationery's Office, 1963), 170.

42 Knappert, Geschiedenis van de Nederlandsche Bovenwindsche eilanden, 218-219. Cf. for Statian illegal trade on St. Lucia in the 1770s: Daniel Marc Antoine Chardon and Louis Nicolas Pretrel, Essai sur la colonie de Sainte-Lucie. Par un ancien intendant de cette isle (Neuchatel: l'Imprimerie de la Société Typographique, 1779), 73.

43 Three decades later, in 1779, when an Anglo-French War raged, the Statians monopolized the food supply to Guadeloupe. Anne Pérotin-Dumon, La ville aux îles, la ville dans l'île: Basse-Terre et Pointe-à-Pitre, Guadeloupe, 1650-1820 (Paris: Éditions Karthala, 2000), 153, 181. Both Statian and Guadeloupean vessels were instrumental in maintaining the mutual commercial ties. When in 1781 news of the British declaration of war against the Dutch arrived on the French island, 24 schooners and brigantines were about to sail to Statia. Gérard Lafleur, "Saint-Eustache aux XVII ${ }^{\mathrm{e}}$ et XVIII ${ }^{\mathrm{e}}$ siècles," Bulletin de la Société d'Histoire de la Guadeloupe 130 (2001), 27-45, 39 
Statia experienced its own crisis in the last quarter of the eighteenth century, immediately following its "Golden Age," which saw an unprecedented volume of imports and re-exports in the 1770s. After a few hundred islanders had perished in hurricanes in $1780,{ }^{44}$ a British naval squadron under Admiral George Rodney punished Statia in February 1781 for its massive support of the American rebels in the form of arms and ammunition. The raid was very costly. Not only did Rodney seize three million British pounds worth of ships, merchandise, and property, another four million pounds worth of bullion was stolen from the residents as well. ${ }^{45}$ To add insult to injury, the French authorities opened some free ports on Guadeloupe, starting in $1785 .{ }^{46}$ And yet, Statia did not decline yet, as its exports in the early 1790 seached levels almost comparable to the mid-1770s. ${ }^{47}$ Nor did the island suffer from the Haitian Revolution, since Saint-Domingue had never been more than a marginal trading partner. The French invasion of the Dutch Republic of 1795, the establishment of the Batavian Republic, and the consequent long-term interruption of shipping traffic to and from Dutch ports seem, however, to have wreaked havoc on the mercantile community of Oranjestad, many of whose members relocated to other parts of the Caribbean.

\section{The Slave Trade}

If a few historians have studied Curaçao's commerce with the French Caribbean, the later history of the island's slave trade has been almost entirely neglected. ${ }^{48}$ It is clear that slave imports from Africa dwindled after the War of

44 Knappert, Geschiedenis van de Nederlandsche Bovenwindsche eilanden, 287. There is no proof for Sheridan's assertion that 4000 to 5000 people died. Richard B. Sheridan, "The Crisis of Slave Subsistence in the British West Indies during and after the American Revolution," The William and Mary Quarterly, 3rd ser., 33, no. 4 (Oct. 1976): 615-641, 627.

45 Han Jordaan, "St. Eustatius after the British occupation of 1781: failing to adapt to a changing world?" (paper presented at the Dutch Atlantic Connections conference, University of Leiden, August 24-25, 2012), 3-4. http://www.kitlv.nl/pdf_documents/Han_Jordaan_-_St _Eustatius.pdf.

46 P. Butel, "L'essor antillais au XVIII ${ }^{\mathrm{e}}$ siècle," in Histoire des Antilles et de la Guyane, ed. Pierre Pluchon (Toulouse: Edouard Privat, 1982), 109-139, 134.

47 Jordaan, “St. Eustatius after 1781," 2; J. de Hullu, “St. Eustatius, St. Martin en Saba op het laatst van de 18de eeuw," De West-Indische Gids 1 (1919), 385-393, 390.

48 The exceptions are Postma, Dutch in the Atlantic Slave Trade, 221-222, Jordaan, "The Curaçao Slave Market," and Han Jordaan, "Slavernij en vrijheid op Curaçao: De dynamiek van een achttiende-eeuws Atlantisch handelsknooppunt" (unpublished PhD diss., University of Leiden, 2012), 52-57. 
the Spanish Succession (1701-1713), during which the Dutch colony acted for the last time as a transit center for the asiento slave trade to the Spanish colonies. The Colonial Council in Dutch Elmina on the African Gold Coast informed the West India Company Board in 1716 that, henceforth, no slaves would be sent to Curaçao, since they remained unsold there. Suriname was now the preferred destination..$^{49}$ Indeed, in the subsequent 23 years (1717-1739), no more than 3105 slaves arrived on Curaçao, constituting an average of 135 per year, compared to an annual average of 1049 during the previous four decades $\left(1675^{-1716)}\right.$. Dutch slavers did revive their shipments to Curaçao in times of international warfare, inducing local merchants to add enslaved Africans to the supplies they offered to foreign colonies. Thus, seven slave ships arrived from Africa in the 1740 s and ten more in the period $1755^{-1764 .{ }^{50}}$ Yet even in those years, the numbers did not match those of an earlier period.

What is largely unknown is Curaçao's intra-Caribbean slave trade after the island's involvement in the asiento business came to an end in 1713. An irregular demand for slaves seems to have remained in Spanish America. During the War of Jenkins' Ear Curaçaoan merchants cultivated contacts with the British island of St. Christopher. From there, they brought their human cargoes to Curaçao and had the Africans shipped to the Spanish Main..$^{51}$ After this war, one merchant in Maracaibo imported some 600 slaves from Curaçao over the course of a few years. ${ }^{52}$ To the West of Maracaibo, in Santa Marta and Río Hacha, slaves arrived from the Dutch island in the 1760 s and 1770 s in exchange for local dyewood. ${ }^{53}$ Curaçaoan slaves were also marketed in the French and British colonies. ${ }^{54}$ In the first 17 years after Georgia legalized slavery in 1750 ,

49 NL-HaNA, wIC, 1.05.01.02, inv. no. 103, fol. 109, D.G.A. Engelgraaff Robberts and Council to the wIC, Elmina, 6 July 1716. Cf. the slave market on Curaçao around this year: Han Jordaan, "De veranderde situatie op de Curaçaose slavenmarkt en de mislukte slavenopstand op de plantage Santa Maria in 1716," in Veranderend Curaçao: Collectie essays opgedragen aan Lionel Capriles ter gelegenheid van zijn 45-jarigjubileum bij de Maduro \& Curiel Bank N.V., ed. Henny E. Coomans, Maritza Coomans-Eustatia, and Johan van 't Leven (Bloemendaal: Stichting Libri Antilliani, 1999), 473-501.

50 Calculated on the basis of Postma, Dutch in the Atlantic Slave Trade, 45, 48, 223.

$5^{1}$ Bodmer, "Tropenkaufleute und Plantagenbesitzer," 305.

52 NL-HaNA, WIC, 1.05.01.02, inv. no. 116o, fol. 86, Governor Isaac Faesch to the wIC, Chamber of Amsterdam, Curaçao, 23 January 1751.

53 Antonio de Narváez y la Torre, "El informe sobre la Provincia de Santa Marta y Río Hacha de 1778," in Ensayos costeños de la Colonia a la República: 1770-189o, ed. Alfonso Múnera (N.p.: Colcultura, 1994), 27-73, 71 .

54 Archief Zeeland (AZ), Middelburgse Commercie Compagnie (MCC), 561, fol. 15, Juan Schuurman to the Directors of the MCC, Curaçao, 19 December 1730. 
139 slaves were furnished by Curaçaoans. ${ }^{55}$ It is not unlikely that one of the human cargoes introduced into Georgia carried smallpox. The epidemic that ravaged the port of Savannah in 1764 was said to have arrived from Curaçao. ${ }^{56}$

Curaçaoan traders were also eager to sell to customers in Saint-Domingue, whose demand for slaves was virtually insatiable. ${ }^{57}$ In 1775, planters on Curaçao may have intended to buy slaves from the arriving ship de Jonge Ruijter, but the local traders bought all 238 Africans and shipped them immediately to Saint-Domingue for sale. ${ }^{58}$ Slaves also went in the opposite direction, from Saint-Domingue to Curaçao. In the 1770s, Curaçaoan masters manumitted no fewer than 42 slaves who hailed from the French Antilles. Most of them were creoles from Saint-Domingue, while a few had been born in Île à Vache (just off Southern Saint-Domingue) and Martinique. At least another ten originated in Congo and other parts of Africa, but slave ships had brought them to the French colonies. Conspicuous among the manumitting Curaçaoans are the names of merchants and ship captains conducting trade with Saint-Domingue. ${ }^{59}$ In the same years, letters of freedom were regularly issued by white Frenchmen who happened to find themselves on Curaçao. Without

55 Darold D. Wax, “New Negroes Are Always in Demand': The Slave Trade in EighteenthCentury Georgia," The Georgia Historical Quarterly 68, no. 2 (Summer 1984), 193-220, 198; Gregory E. O'Malley, "Beyond the Middle Passage: Slave Migration from the Caribbean to North America, 1619-1807," The William and Mary Quarterly, 3rd ser., 66, no. 1 (January 2009): 125-172, 150.

$5^{6}$ Joseph I. Waring, "Colonial Medicine in Georgia and South Carolina," The Georgia Historical Quarterly 59 (1975), supplement, 151-153, 152. The Africans probably came from Angola, a common source of smallpox epidemics in Brazil and in particular associated with the 1762-1763 epidemic in Maranhão: Dauril Alden and Joseph C. Miller, "Out of Africa: The Slave Trade and the Transmission of Smallpox to Brazil, 1560-1831," The Journal of Interdisciplinary History 18, no. 2 (1987): 195-224, 207. In late 1763, one slave ship arriving from the Angolan Coast disembarked 405 Africans on Curaçao: Postma, Dutch in the Atlantic Slave Trade, app. 2, 337. There is no sign, however, that the 1750 slave revolt on Curaçao hampered sales of black men and women, although the governor of St. Christopher did worry that the insurrection "might have a dangerous influence upon our own Slaves." David Barry Gaspar, Bondmen \& Rebels: A Study of Master-slave Relations in Antigua with Implications for Colonial British America (Baltimore and London: The Johns Hopkins University Press, 1985), 210.

57 AZ, MCC 562, fol. 305, Michiel Römer to the Directors of the MCC, Curaçao, 11 November 1772 .

$5^{8}$ NL-HaNA, wIC, 1.05.01.02, inv. no. 1166, fol. 17, Governor Jean Rodier to the wIC, Chamber of Zeeland, Curaçao, 10 January 1775.

59 The names were Benjamin Motta, Gabriel Pinedo, Isaak Sasso, Claes Schotborgh Janzn, Johannes de Pool, Lourents de Mey Scholten, Isaac Cardoso da Costa, and Isaac Pardo; 
an exception, they were merchants, although it is unclear whether they traveled in the company of the slaves they freed. ${ }^{60}$

After 1780 , the archives are increasingly silent about the slave trade. ${ }^{61}$ Shipments now typically involved three, four or half a dozen slaves, whereas past supplies to foreign American markets had sometimes numbered in the hundreds. If warfare had opened up slave markets in decades past, the American Revolutionary War failed to do so for Curaçao. After the war's end, it was evident that owners of slave ships in the Dutch Republic preferred to deal with Suriname, Berbice, Essequibo, and Demerara. In 1786, six years after the last slave ship had arrived from Africa, Curaçao's ruling Council did still not give up its hope to restore the trade in human cargoes, revealing a project to use the slave trade to reinvigorate commerce with the Spanish colonies. ${ }^{62}$ This was no idle talk. Shortly afterwards, one local merchant approached the viceroy of New Granada with a plan to supply slaves to any part of the viceroyalty. ${ }^{63}$ The initiative was bound to fail, since Spanish Americans could now procure their enslaved workers through numerous other channels. The ban issued in Venezuela on importing slaves from the Dutch island after the slave revolt of August 1795, therefore, did not cause, but merely hastened, the demise of the Curaçaoan slave market. ${ }^{64}$

\section{Commercial Actors and Practices}

Who were the residents of Curaçao, whose fate was inextricably bound up with the vicissitudes of interimperial trade? We know much about Curacao's contraband trade on an aggregate level, but little about the various groups of

T. van der Lee, Curaçaose vrijbrieven 1722-1863: Met indices op namen van vrijgelatenen en hun voormalige eigenaren (Den Haag: Algemeen Rijksarchief, 1998), 158-6o, 163-164, 170, $175^{-176,180,182,184-185 .}$

6 Why, for example, would Jean Tapiau have traveled with five slaves (three adult females, one male, and one child), whom he emancipated on Curaçao on 28 February 1774 ? And why would Jean Jacques Chatelain be accompanied by six children, two women, and one man, whom he freed on 29 September 1773 ?

61 A rare case of slave sales in the 1780 s, involving a merchant from Guadeloupe, occurred in 1783: Pérotin-Dumon, La ville aux îles, la ville dans l'île, 193.

62 NL-HaNA, wIC, 1.05.01.02, inv. no. 613, fols. 1034-1035, Johannes de Veer and Michiel Römer to the wic, Curaçao, 1 May 1786.

63 Archivo General de la Nación, Colombia [Bogotá], Colonia, Panamá. Online at http:// negrosyesclavos.archivogeneral.gov.co/portal/apps/php/documentacion.kwe.

64 Miguel Acosta Saignes, Vida de los esclavos negros en Venezuela (La Habana: Casa de las Américas, 1978), 88-89. 
islanders involved in interimperial trade. The least pecunious group, apart from the enslaved residents, were the sailors, who formed a significant part of Willemstad's population. At the start of the Fourth Anglo-Dutch War in 1781, crew members sailing on local trading vessels numbered no fewer than $832 .{ }^{65}$ These men usually supplemented their monthly wages by engaging in petty trade. Buying small amounts of merchandise on credit from metropolitan merchants or local shipowners, the sailors brought these commodities wherever their vessels took them. The risks were manifold, since ship and cargo could be seized by enemies, pirates, and coastguard ships seeking to intercept contraband goods. In the event the ship was captured, the sailor lost his wage and his trading goods, and still had to pay his creditors. In the 1750s, scores of sailors' families were thus impoverished and condemned to eat what was considered slave food. ${ }^{66}$

Local merchants and shipowners were the ones usually taking the initiative in organizing the trading voyages. Most of them were not monied men. One governor wrote that the island's trade was conducted by less well-off people who bought a sloop on credit and could not afford to pay it off until the sloop's return. ${ }^{67}$ Investing all their fluid assets in a single voyage, shipowners were, indeed, usually not men of substance. Agreements with Dutch sellers of European dry goods for the Spanish American markets therefore stipulated payment only after the completion of a trading expedition to the Spanish Main. ${ }^{68}$ Among the local traders, Sephardi Jews dominated. Enjoying religious freedom on Curaçao and fluent in Spanish, they established widespread commercial contacts in the nearby Spanish colonies. ${ }^{69}$

Most local shipowners were connected to merchants in Amsterdam or Middelburg, while others purchased goods from ships that arrived from Dutch metropolitan ports or from local import-export companies. A Curaçaoan trader by the name of Van Lennep, for example, involved in both re-exports to the Spanish Main and the French Caribbean, did business with Thomas and Adriaan Hope of Amsterdam. Interestingly, the

65 NL-HaNA, WIC, 1.05.01.02, inv. no. 1173, meeting of the War Council, Curaçao, 26 February 1781.

66 NL-HaNA, WIC, 1.05.01.02, inv. no. 599, fols. 912-913, J.G. Pax and Nathaniel Ellis to Governor Isaac Faesch and the Council, Curaçao, 24 September 1753.

67 NL-HaNA, wIC, 1.05.01.02, inv. no. 591, fol. 162, Governor Isaac Faesch to the wIC, Curaçao, 30 April 1744. See also Jordaan, "Slavernij en vrijheid," 164-167.

68 Bodmer, "Tropenkaufleute und Plantagenbesitzer," 303.

69 Wim Klooster, "Contraband Trade by Curaçao's Jews with Countries of Idolatry, 1660180o," Studia Rosenthaliana 31, nos. 1-2 (1997): 58-73. 
Hope brothers paid the costs of the transport of indigo from SaintDomingue to Curaçao. ${ }^{70}$

Detailed information is available regarding two Curaçaoan companies, which will provide some insights into the multiplicity of commercial contacts that existed between the Dutch island, on the one hand, and Europe and the Americas, on the other. One of these two companies was co-founded by Isaac Faesch (1687-1758), a Swiss native who was Curaçao's governor from 1740 through 1758. After fighting on both sides during the War of the Spanish Succession, Faesch joined the company of his brother Johann Rudolf in Amsterdam. Their activities included the dispatch of French and Dutch textiles to the Caribbean. After his brother's premature death in 1718, Isaac continued the business with his widowed sister-in-law, but lost most of its capital by speculating in shares of the Compagnie d'Occident, a joint-stock company that had received monopoly trading rights in the Caribbean and North America from the French government. As profits could not keep up with speculation in the company's shares, in 1720 the bubble burst. Isaac's fortunes changed after he took up his duties at the Dutch West India Company and his appointment as commander of St. Eustatius. En route to his destination, Faesch met Johann Jakob Hoffmann, a fellow native of Basel, whom he may have known before. Hoffmann was on his way to become the secretary of the neighboring Dutch colony of St. Martin, but beyond his administrative expertise, he had unmistakable commercial talents as well. The two soon joined hands as business associates and founded a company on St. Eustatius. Following Faesch's appointment as governor of Curaçao in 1740, they dissolved their company. Hoffmann became the company's front man, since Faesch was told by the West India Company to discontinue his commercial pursuits. ${ }^{71}$ During the next two years, Hoffmann displayed tremendous commercial activity before returning to Europe and leaving the company to Isaac's nephew, the son of the governor's merchant brother.

It was men like Faesch and Hoffmann who constructed the ever closer commercial ties between Curaçao and the French West Indies. Both men were agents for firms in Amsterdam, Haarlem, and Leiden, receiving their products

70 Chassaigne, "L'économie des îles sucrières," 101.

71 The prohibition did not convince the governor to abandon his commercial pursuits. It seems more than a little suspicious that over 60,00o pesos were found among his possessions upon his death: Han Jordaan, "James Love en 'des Zwitsers hand': Van kaapvaart, contrebande en geruchten van corruptie," in Caraïbische cadens: Liber Amicorum opgedragen aan de Gevolmachtigde Minister van de Nederlandse Antillen, ed. Henny E. Coomans, Maritza Coomans-Eustatia, and Peter Prins (Bloemendaal: Stichting Libri Antilliani, 1995), 258-65, 264. 
on consignment and selling them in Curaçao or sending them on to their own agents on other Dutch islands. Alongside their commission business, both men exported colonial American crops for their own account, which they sent to Amsterdam. There, they maintained commissioners who sold on commission. The crops included sugar from Guadeloupe, Martinique, and SaintDomingue, tobacco from Puerto Rico, Santo Domingo, and St. Vincent, coffee from Guadeloupe and Martinique, and cacao from Venezuela. In addition, the couple from Basel arranged for the sale of these same products to the Dutch Republic for the account of locally established Dutch merchants. On behalf of French merchants, they also sold products from Guadeloupe and Martinique in Amsterdam. In addition, Hoffmann was involved in purchasing slaves from the British islands, planning at one point to bypass the tax on slaves who arrived in Willemstad by dressing the slaves up as sailors. Hoffmann frequently acted as an agent of the Dutch merchants in St. Eustatius, on whose orders he sold goods they had received directly or indirectly from Europe and North America, in particular provisions such as meat, bacon, flour, oranges, and potatoes. At the same time, Hoffmann purchased cacao, hides, and mules for the Statians, which they then resold. Hoffmann seems to have been involved in virtually every imaginable commercial pursuit. He was an intermediary in the sale of ships, provided vessels in transit with provisions, paid crews' wages on behalf of his superiors, and took part in the money changing business. And, finally, Faesch and Hoffmann were active in brokerage and in the insurance business, insuring both regular inter-Caribbean trade and smuggling ventures by Curaçaoan and French West Indian vessels.

The sale of European products on Curaçao and the re-export of American products to Europe were parallel worlds, although they were not each other's mirror image. Most re-exported crops originated in French America, while Spanish America was the main destination for most European manufactures introduced on Curaçao. Faesch and Hoffmann themselves were not involved in the illicit trade with the Spanish colonies, preferring to sell the manufactures to a wide variety of small shipowners who sent their own vessels to the shores of Spanish America.

These manufactures imported from the Republic were varied. Textiles formed the main category, especially linen and woolen materials. Fine linen originating in France and Flanders, coarse Dutch linen, and decorated linen from Silesia and Bohemia called platillas were all destined to find a ready market in the Spanish colonies. Luxury products included white satin, black satin crêpe, grey silk fabric, as well as richly decorative brocades made in silk fabric and embroidered with gold and silver, garters, hats, and buttons with threads of gold and silver. For a larger clientele, both locally and foreign, Faesch and 
Hoffmann also procured hawsers, sailcloth, mirrors, brandy, Madeira wine, provisions, and spices from the East Indies. They obtained some of these items from the company where Faesch had worked in Amsterdam, the same one that sold sugar and tobacco for Faesch and Hoffmann in Amsterdam. ${ }^{72}$

In 1778 , a few decades after Hoffmann's whirlwind Caribbean career, another European merchant moved to Curaçao. Pierre Brion (c.1751-1799), born in a village near Liège and raised in Amsterdam, arrived in Willemstad as the factor of the Amsterdam-based firm Turri \& Co. (later succeeded by Tonella \& Co.). In due course, Brion came to represent four other Amsterdam companies. Apart from loading ships sailing exclusively for Turri \& Co., Brion organized the shipment of company goods on other vessels leaving Amsterdam for Curaçao. In the Caribbean, he developed ties to virtually every major port on the Spanish Main, including Cumaná, La Guaira (and nearby Caracas), Coro, Río Hacha, Santa Marta, Maracaibo, and Cartagena, as well as with a few ports in Santo Domingo, Puerto Rico, and Saint-Domingue, Especially Cap Français, Les Cayes, and Jacmel. In 1781 alone, two vessels that Brion had fitted out for the Curaçao-Cap Français run were captured by English privateers. In the last years of his life, when his reputation earned him a position on the island's council, he added contacts in St. Thomas and ports on the Eastern seaboard of the United States. ${ }^{73}$ In the wide range of his endeavors, Brion resembled Hoffmann. He bought and sold ships (and, on one occasion, gunpowder) across imperial borders, collected debts in foreign colonies on behalf of other foreigners, and assumed the administration of one Curaçaoan plantation. ${ }^{74}$

In the year before he moved to Curaçao, Brion - already in the employ of Turri \& Co. - had visited the two brothers Joseph Anton and Peter Paul Obwexer in Augsburg, who ran a banking firm that had branched out into the textile business, buying textiles throughout Germany and running a cotton factory. The company hired Brion as their factor on Curaçao, using Turri \& Co. as their agents in Amsterdam. ${ }^{75}$ One of Brion's main tasks was to determine which manufactures Obwexer had to send in order to buy the usual New World

\footnotetext{
72 Bodmer, "Tropenkaufleute und Plantagenbesitzer," 290-305.

73 Mark Häberlein and Michaela Schmölz-Häberlein, Die Erben der Welser:Der Karibikhandel der Augsburger Firma Obwexer im Zeitalter der Revolutionen, Studien zur Geschichte des Bayerischen Schwabens 21 (Augsburg: Dr. Bernd Wißner, 1995), 65, 87-94, 102-104.

74 Ibid., 89-90, 92.

75 Obwexer was not the first German textile firm to forge a connection to Curaçao. Abraham Dürninger \& Co. from Herrnhut in Saxony, a leading linen exporter, maintained a warehouse in Willemstad: Jörg Ludwig, Der Handel Sachsens nach Spanien und Lateinamerika, 1760-1830: Warenexport, Unternehmerinteressen und staatliche Politik (Leipzig: Nouvelle Alliance, 1994), 75, 124.
} 
products of cacao, tobacco, sugar, coffee, and hides, but also cotton and indigo. He kept himself abreast of changes in fashion in the Spanish and French colonies, describing in detail in two letters from 1780 the types of printed cottons of which he wanted to order two chests. The best colors for this fabric printed in a floral pattern were, he argued, dark violet, pink, red, blue, and coffee brown. Another chest of cottons had to be printed in very fine brocade patterns with stripes that were not too wide, and moderately priced, since the brocade fashion was fading. On this occasion alone, Brion ordered 15 chests of printed cottons, 11 chests of calicoes, and eight chests and 900 pieces of other cottons. ${ }^{76}$

\section{Curaçaoan Mobility}

By the mid-eighteenth century, Willemstad's wharves lined "both sides of the bay deep into the interior, well past the fort and port complex at the harbor entrance," to accommodate the expanding shipping traffic. ${ }^{77}$ Population growth had accompanied the port's development. In the 1660 , the population had been so small that the arrival of a slaver put a serious strain on the food supply, since the residents had to share the provisions with the disembarked Africans. ${ }^{78}$ It was not until the early eighteenth century that the town, which in the past had been overshadowed by the military base, transformed into a fullfledged port city. In 1789, when Curaçao's only eighteenth-century census was taken, 11,543 people called the city home, making it the nineteenth port city in Atlantic America, substantially smaller than Havana, Salvador and Rio de Janeiro, similar in size to the estimated population of Paramaribo, and more or less comparable to Charleston or Cartagena de Indias (Table 1.1). At the same time, Willemstad was the seventh port in the insular Caribbean, smaller only than Havana, Kingston, Cap Français, Santiago de Cuba, and Bridgetown, larger than Santo Domingo, Port-au-Prince, and San Juan (Puerto Rico) (Table 1.2), and much larger than Oranjestad. Most of these ports had seen their populations grow in the same period, from the late seventeenth to the late eighteenth century.

\footnotetext{
76 Häberlein and Schmölz-Häberlein, Erben der Welser, 19, 60-62.

77 Linda M. Rupert, Creolization and Contraband:Curaçao in the Early Modern Atlantic World (Athens, Ga. and London: The University of Georgia Press, 2012), 129.

$7_{8}$ Resolution, wiC Chamber of Amsterdam, 13 June 1669, in Documenten behoorende bij 'De Nederlanders op de West-Indische Eilanden', ed. J.H.J. Hamelberg, 2 vols. (Amsterdam: De Bussy, 1901-03), 1,83.
} 
Attention has traditionally focused on the activities of merchants in shaping Curaçao's transit center. As organizers of trading ventures, they provided the island with an economic foundation, and did so in the face of multiple challenges. When Johann Hoffmann returned to the Old World in 1742, he considered a young man with a job in Europe infinitely happier than the foremost merchant in the Americas, where fortunes were no longer made so fast. ${ }^{79}$ The merchants were, of course, not alone in constructing Curaçao's commercial world. Sailors, fishermen, caulkers, dockhands, warehouse workers, and sailmakers were all needed to keep the entrepôt afloat. As the eighteenth century advanced, more and more blacks and colored men held these jobs and by midcentury, slaves came to dominate the port-related occupations. Members of the island's ruling Council estimated as early as 1741 that two-thirds of the sailors were either slaves or free people of color, a share that only increased in the decades ahead. ${ }^{80}$

TABLE 1.1 Top Twenty Port City Populations of Atlantic America, circa 1790.

\begin{tabular}{lll}
\hline Port & Inhabitants & Date \\
\hline Havana & 44,337 & 1791 \\
Salvador & 39,209 & 1780 \\
Rio de Janeiro & 38,707 & 1780 \\
New York & 33,131 & 1790 \\
Buenos Aires & $29,920^{*}$ & 1778 \\
Philadelphia & $28,5^{22}$ & 1790 \\
Kingston & 26,478 & 1788 \\
Saint-Pierre (Martinique) & 1788 \\
Boston & $20,000^{*}$ & 1790 \\
Recife & 18,320 & 1776 \\
Campeche & 18,207 & 1766 \\
Charleston & $18,000^{*}$ & 1790 \\
Cap Français & 16,359 & 1788 \\
Santiago de Cuba & 15,696 & 1792 \\
Bridgetown (Barbados) & $15,000^{*}$ & 1773
\end{tabular}

79 Bodmer, "Tropenkaufleute und Plantagenbesitzer," 305.

8o NL-HaNA, WIC, 1.05.01.02, inv. no. 588, fol. 89o, information provided by delegates of the Council of Curaçao, J.G. Pax, Johannes Stuijlingh, and Jan van Schagen, 18 June 1741. 
TABLE 1.1 Top Twenty Port City Populations of Atlantic America, ca. 179o. (cont.)

\begin{tabular}{lll}
\hline Veracruz & $14,000^{*}$ & 1790 \\
Cartagena de Indias & 13,690 & 1777 \\
Baltimore & 13,530 & 1790 \\
Paramaribo & $11,760^{*}$ & 1791 \\
Willemstad & 11,543 & 1789 \\
\hline
\end{tabular}

The population figures with an asterisk are estimates.

Sources: Havana: María Dolores González-Ripoll Navarro, Cuba, isla de los ensayos: Cultura y sociedad (1790-1815) (Madrid: CSIC, 2000), 109; Salvador: A.J.R. Russell-Wood, "Ports of Colonial Brazil," in Atlantic Port Cities: Economy, Culture, and Society in the Atlantic World, 1650-1850, ed. Franklin W. Knight and Peggy K. Liss (Baltimore: The Johns Hopkins University Press, 1991), 196-239, 222; Rio de Janeiro and Recife: Jacob M. Price, "Summation: The American Panorama of Atlantic Port Cities," in Atlantic Port Cities, ed. Knight and Liss, 262-76, 263; New York, Philadelphia, Boston, Baltimore, and Salem: United States census of 1790: http://www.census.gov/population/www/documentation/twpsoo27/tabo2.txt; Buenos Aires: Lyman L. Johnson, "Estimaciones de la población de Buenos Aires en 1744, 1778 y 1810," Desarrollo Económico 19, no. 73 (April-June 1979): 107-119; Kingston: Emma Hart and Trevor Burnard, "Kingston, Jamaica, and Charleston, South Carolina: A New Look at Comparative Urbanization in Plantation Colonial British America," The Journal of Urban History 39, no. 2 (March 2013): 214-234, 7; Saint-Pierre: Frédéric Régent, La France et ses esclaves: de la colonization aux abolitions (1620-1848) (Paris: Éditions Grasset \& Frasquelle, 2007), 120; Campeche: Adriana Delfina Rocher Salas, "Religiosidad e identidad en San Francisco de Campeche. Siglos XVI y XVII," Anuario de Estudios Americanos 63, no. 2 (2006): 27-47, 44, no. 39; Cap Français: Paul Butel, Histoire des Antilles françaises, $X V I I^{e}-X X^{e}$ siècle (s.l.: Perrin, 2002), 190; Santiago de Cuba: Leví Marrero, Cuba: economía y sociedad. Azúcar, Ilustración y conciencia (1763-1788) (Madrid: Editorial Playor, 1983), 147; Bridgetown: Pedro L.V. Welch, Slave Society in the City: Bridgetown, Barbados, 1680-1834 (Kingston: Ian Randle Publishers \& Oxford: James Currey Publishers, 2003), 53; Veracruz: my calculation, based on Jackie R. Booker, Veracruz Merchants, 1770-1829: A Mercantile Elite in Late Bourbon and Early Independent Mexico (Boulder, Col.: Westview Press, 1993), 7; Cartagena de Indias: Manuel Lucena Giraldo, A los cuatro vientes: Las ciudades de la América hispánica (Madrid: Fundación Carolina Centro de Estudios Hispánicos e Iberoamericanos, Marcial Pons Historia, 2006), 141; Paramaribo: Cornelis Ch. Goslinga, The Dutch in the Caribbean and in the Guianas 1680-1791 (Assen, Maastricht and Dover, New Hampshire: Van Gorcum, 1985), 519; Willemstad: Wim Klooster, Illicit Riches: Dutch Trade in the Caribbean, 1648-1795 (Leiden: KITLV Press, 1998), 61; In 1790, São Paulo and adjacent parishes had over 8000 inhabitants: Richard M. Morse, From Community to Metropolis: A Biography of São Paulo, Brazil (Gainesville: University of Florida Press, 1958), 30. 
TABLE 1.2 Top Ten Port City Populations of the Insular Caribbean, ca. 1790.

\begin{tabular}{lll}
\hline Port & Inhabitants & Date \\
\hline Havana & 44,337 & 1791 \\
Kingston & 26,478 & 1788 \\
Saint-Pierre & $20,000^{*}$ & 1788 \\
Cap Français & 15,696 & 1788 \\
Santiago de Cuba & $15,000^{*}$ & 1792 \\
Bridgetown & $14,000^{*}$ & 1773 \\
Willemstad & 11,543 & 1789 \\
Santo Domingo & 10,702 & $1782-1783$ \\
Port-au-Prince & 6200 & 1789 \\
San Juan & 6005 & 1771 \\
\end{tabular}

The population figures with an asterisk are estimates.

Sources: see Table 1.1; San Juan: Bibiano Torres Ramírez, La isla de Puerto Rico (1765-180o) (San Juan de Puerto Rico: Instituto de Cultura Puertorriqueña, 1968), 16; Santo Domingo: Maria Rosario Sevilla Soler, Santo Domingo Tierra de Frontera (1750-180o) (Sevilla: Escuela de Estudios Hispano-Americanos, 1980), 35; Port-au-Prince: David Geggus, "The Major Port Towns of Saint Domingue in the Later Eighteenth Century," in Atlantic Port Cities, ed. Knight and Liss, $87-116,108$.

Although blacks working in the maritime economy often did not work under close supervision of their masters, they still longed for more autonomy. The maritime economy itself helped them escape from slavery. Since the island was too small to accommodate viable maroon communities, maritime flight offered the only alternative. Stealing a boat and rowing to Venezuela was the main route to freedom, especially since slaves were declared free upon arrival if they announced their willingness to convert to Catholicism. Other black sailors simply absconded during trading voyages. ${ }^{81}$ Still, most slaves traveling on board trading vessels stayed put. One of these slaves, a man named Jean, accompanied his master, the merchant David Senior, to Cap Français in June 1793, when, on the 2oth of that month, one of the landmark events of the Haitian Revolution took place. That day saw street fighting between whites and colored people, slaves being freed from jails, and multiple fires spreading

81 Linda M. Rupert, "Marronage, Manumission and Maritime Trade in the Early Modern Caribbean," Slavery \& Abolition 30, no. 3 (2009), 361-382, 364. 
through the city. Jean apparently protected his master and was rewarded with manumission two weeks later. ${ }^{82}$

Curaçao's government repeatedly took precautions to prevent slaves from fleeing. A law from 1742 made it illegal for captains sailing from Curaçao to take on blacks and mulattoes who failed to produce a document that proved their freedom. The law was at odds with the practice of many urban slaveholders to employ their slaves on board the trading vessels. This was in itself risky, since capture by a Spanish coastguard vessel might result in the auctioning off not only of the ship and the trade goods, but of enslaved crew members. ${ }^{83}$ The slaveholders' solution was to issue temporary manumissions, which offered slaves protection against pirates and privateers, and shielded their owners from the loss of their human property. Linda Rupert has found 153 such pro forma manumissions for the period $1741-1775 .{ }^{84}$

The main destination of maritime maroons was Coro in Venezuela, where over the course of the century countless enslaved Curaçaoans embraced a life of freedom upon formal conversion to Catholicism. ${ }^{85} \mathrm{In}$ the year 1774 alone, with Curaçao facing a severe food crisis, 140 slaves succeeded in escaping from the island to Coro. That number could have been even higher if the massive flight attempted by all 72 slaves from the de Fuijk plantation in October of that year had been crowned with success. The large canoe that they stole to make their way to Coro was, however, spotted by watchmen who started yelling and were soon joined by some fishermen. The slaves then went back ashore and withdrew to the woods. Most were eventually captured and many were sold to Saint-Domingue. ${ }^{86}$ By the closing years of the century, no fewer than 400 former Curaçaoans lived in the Southern part of the Venezuelan town, while other refugees had moved on to nearby mountainous terrain or runaway communities. ${ }^{87}$ Nor did they relinquish their ties to what had often been their native island. Various

82 Van der Lee, Curaçaose vrijbrieven, 288.

83 From 1730 through 1737 , at least 51 black and four mulatto Curaçaoans were seized off the Venezuelan coast by coastguard ships fitted out by the Compañía Guipuzcoana: NL-HaNA 1.05.12.01, Curaçao, Bonaire en Aruba tot 1828, inv. no. 806, fols. 622ff, Notes from the Governor and Council, January-June 1747.

84 Rupert, "Marronage," 370-372.

85 Many - if not most - of them were already Catholics upon arrival, but the local priests were probably unaware of this.

86 NL-HaNA, wIC, 1.05.01.02, inv. no. 1166, fol. 17, Governor Jean Rodier to the wIC, Chamber of Amsterdam, Curaçao, 10 January 1775.

87 Lucas Guillermo Castillo Lara, Curiepe: Orígenes históricos (Caracas: n.p., 1981), 61, 285. Ramón Aizpurua, "En torno a la aparición de un pueblo de esclavos fugidos de Curazao en 
religious brotherhoods in both places maintained close ties in the 1760 s and 1770s, one of which in Coro sent delegates to the Dutch island to collect alms from their brothers. ${ }^{88}$

Although Venezuelan slaves rarely went in the opposite direction, perhaps the most notorious person in their midst did flee to Curaçao. Andresote, a man described as a maroon, rallied a large group of Indians and runaway slaves in the early 1730s, allegedly committing crimes in defiance of the authorities, who attempted to root out the contraband trade with Curaçao. ${ }^{89}$ Andresote's followers included blacks from Coro who had successfully escaped from the Dutch island. Shielded by armed Curaçaoan traders, Andresote fled from Venezuela to Curaçao, where he was described several years later as a runaway, who had committed murders and other crimes. As before in Venezuela, he counted many maroons among his supporters. ${ }^{90}$

Most slaves were not so fortunate to find freedom. They spent their lives in bondage on Curaçao or were shipped off to other parts of the Caribbean. Once they moved to foreign soils, exported slaves usually stopped leaving traces. Only during extraordinary circumstances, especially insurgencies, do we find references to slaves from Curaçao, and presumably only to those born on the island. One of the suspects in the 1741 conspiracy in New York City was Curacoa Dick. Although his master, the Dutch American Cornelius Tiebout, testified on his behalf, he was sentenced with three others to be burnt at the stake. ${ }^{91}$ Curaçaoans were also found among maroons in South Carolina, SaintDomingue, and Santo Domingo. ${ }^{92}$ Natives of Curaçao who turned maroon in

la Sierra de Coro en el siglo XVIII," Boletín de la Academia Nacional de la Historia [Caracas], 87-345 (2004): 109-28.

88 Rupert, Creolization and Contraband, 179.

89 Carlos Felice Cardot, La rebelión de Andresote (Valles de Yaracuy, 1730-1733): Discurso de recepción como individuo de número de la Academia Nacional de la Historia (Caracas: Impr. Nacional, 1952). Another case involving a flight from Venezuela to Curaçao ended badly for the slave in question. On Curaçao the refugee, Juan Inocencio, earned his living as a sailor but when his vessel reached Chuao in 1772 and he went ashore, he was recognized as having fled from that town and put in chains: Carlos Salazar et al., La Obra Pía de Chuao 1568-1825 (Caracas: Universidad Central de Venezuela, 1968), 349.

$90 \quad$ Klooster, Illicit Riches, 153-154.

91 Thomas J. Davis, A Rumor of Revolt: The "Great Negro Plot" in Colonial New York (New York: The Free Press and London: Collier Macmillan Publishers, 1985), 65, 121. This conspiracy probably only existed in the imagination of the white population: Philip D. Morgan, "Conspiracy Scares," The William and Mary Quarterly, 3rd ser., 59, no. 1 (January 2002): 164-165.

92 Perry L. Kyles, "Resistance and Collaboration: Political Strategies within the AfroCarolinian Slave Community, 1700-1750," The Journal of African American History 93, no. 4 
Saint-Domingue probably included Marie, a woman described as "Dutch." She escaped from her master, an apothecary on board a ship in Cap Français, when she was eight months pregnant. ${ }^{93}$ In Santo Domingo, runaways joined the exclusively male floating population of a runaway logwood community, where they were described in the year 1790 as living "without God, law or King." During the 1795 Pointe Coupée conspiracy in Louisiana, a creole slave from Curaçao encouraged slaves to rebel by telling the story that "they are awaiting at the Capital an Order of the King which declares all the slaves free..." ${ }^{94}$ Finally, a slave named José María Curazao informed the overseer of a Cuban sugar mill in 1798 about an imminent slave insurrection. Among the leaders of the revolt were apparently, once again, Curaçaoans. ${ }^{95}$

Like their enslaved brother and sisters, free Curaçaoans of color were remarkably mobile, sojourning and settling in a variety of foreign colonies. ${ }^{96}$ One of them took part in the British siege of Havana in 1762. Towards the end of the siege, the "sailor Francisco Antonio, a black man from Curaçao" was listed as one of the deserters of the expedition that the Spanish kept in jail.97 Most of these itinerant men and women traveled individually, but at least in one place, a large group of Curaçao-born blacks and mulattoes settled down. A total of 156 of them lived on the Danish island of St. Thomas in 1803, representing the largest contingent of people of color not native to that island, with native Statians occupying third place. The women in their midst listed

(Fall 2008): 502. Bernard Foubert, "Le marronage sur les habitations Laborde à SaintDomingue dans la seconde moitié du XVIII e siècle," Annales de Bretagne et des pays de l'Ouest 95, no. 3 (1988): 277-310, 287. Martín Lienhard, Disidentes, rebeldes, insurgentes: Resistencia indígena y negra en América Latina. Ensayos de historia testimonial (Frankfurt: Iberoamericana Vervuert, 2008), 97-98.

93 Jason Daniels, "Recovering the Fugitive History of Marronage in Saint-Domingue, 17701791," Journal of Caribbean History 46, no. 2 (2012): 134-35.

94 Gwendolyn Midlo Hall, Africans in Colonial Louisiana: The Development of Afro-Creole Culture in the Eighteenth Century (Baton Rouge, London: Louisiana State University Press, 1992), $35^{2}$.

95 María Dolores González-Ripoll, Consuelo Naranjo, Ada Ferrer, Gloria García, and Josef Opatrný, El rumor de Haití en Cuba: temor, raza y rebeldía, 1789-1844 (Madrid: Consejo Superior de Investigaciones Científicas, 2004), 280.

96 For the free people of color in general, see Wim Klooster, "Subordinate but Proud: Curaçao's Free Blacks and Mulattoes in the Eighteenth Century," New West Indian Guide/ Nieuwe West-Indische Gids 68, nos. 3-4 (1994): 283-300; Han Jordaan, "Free Blacks and Coloreds in the Administration of Justice in Eighteenth-Century Curaçao," New West Indian Guide 84, nos. 1-2 (2010): 63-86.

97 Elena Schneider, "The Occupation of Havana: War, Trade, and Slavery in EighteenthCentury Cuba," (unpublished PhD diss., Princeton University, 2011), 230. 
themselves as seamstresses and cooks, but were in reality petty traders whose knowledge of Spanish and Spanish customs served them well. ${ }^{98}$

The trading routes also enabled free blacks and mulattoes from other parts of the Caribbean to make their way to Curaçao. Those from Spanish-speaking areas came to squat on plantations and on the conucos, the small plots of land cultivated by free and enslaved Curaçaoans. On various occasions, the government took action against them by forcing them to help repair the main fort or threatening them with forced labor if they did not leave within two weeks. ${ }^{99}$ Alternatively, the authorities used the free foreign non-whites to boost the militia ranks. ${ }^{100}$

\section{Conclusion}

The main commercial development in eighteenth-century Curaçao was the intensification of contacts with the French Caribbean. While merchants in metropolitan Dutch ports and their Curaçaoan correspondents had previously used the island primarily as a gateway to the Spanish American markets, they now discovered the possibilities of trade with Guadeloupe, Martinique, and Saint-Domingue, producers of vast amounts of sugar, coffee, and indigo. Traders on Curaçao itself sent vessels to these colonies and devised an original way to tap French colonial markets by using their long-established contacts on the Spanish Main to transport mules to the French islands, where these animals propelled the sugar mills.

98 David W. Knight and Laurette de T. Prime, eds., St. Thomas 1803: Crossroads of the Diaspora (The 1803 Proceedings and Register of the Free Colored) (St. Thomas, United States Virgin Islands: Little Nordside Press, 1999); Neville A.T. Hall, Slave Society in the Danish West Indies: St. Thomas, St. John, St. Croix, ed. B.W. Higman (Baltimore and London: The Johns Hopkins University Press, 1992), 180-181.

99 NL-HaNA, WIC, 1.05.01.02, inv. no. 1156, fol. 64, Juan Pedro van Collen to the wic Board, Curaçao, 31 May 1737. Placards of 2 April 1731 and 24 October 1743, in West Indisch Plakaatboek: Publikaties an andere wetten alsmede de oudste resoluties betrekking hebbende op Curaçao, Aruba, Bonaire, 2 vols., ed. J.A. Schiltkamp and J.Th. de Smidt (Amsterdam: Emmering, 1978), 1:156, 234. Spanish-speaking whites who did not report to the authorities would be deported to their colonies of origin: Lucas Guillermo Castillo Lara, La aventura fundacional de los isleños: Panaquire y Juan Francisco de León (Caracas: Academia Nacional de la Historia, 1983), 497.

100 Placards of 4 March and 20 May 1761, in Schiltkamp and De Smidt, West Indisch Plakaatboek, 1:29o. See also NL-HaNA, wIC, 1.05.01.02, inv. no. 6o3, fols. 1193-1194. 
Old and new trading routes alike did not only convey commodities. They also enabled the mobility of the crews of the numerous sloops and schooners owned by islanders, and of free people who could afford the costs of their passage. And while Curaçaoan vessels continued to transport bonded Africans for sale throughout the Caribbean, blacks used the same shipping lanes to escape their enslavement. If, then, for some, the island's interconnectedness offered the promise of profit, for others it signaled the hope of a better life. 